\title{
Removal of Nitrogen and Phosphorus from Wastewater by Modi- fied Pyrite in a Sequencing Batch Reactor (SBR)
}

\author{
Hou-Yun Yang ${ }^{1,2}$, Pei Xu ${ }^{1}$, Hua-Yuan Wang ${ }^{1,2}$, Wei-Hua Li ${ }^{1,2 *}$, Shu-Guang Zhu ${ }^{1,3 *}$ \\ ${ }^{1}$ School of Environment and Energy Engineering, Anhui Jianzhu University, Hefei 230601, China \\ ${ }^{2}$ Key Laboratory of Water Pollution Control and Wastewater Reuse of Anhui Province, Hefei 230601, China \\ ${ }^{3}$ Key Laboratory of Huizhou Architecture in Anhui Province, Hefei 230601, China
}

\begin{abstract}
The removal efficiency of nitrogen and phosphorus is challenging in the conventional biological nitrogen and phosphorus removal processes. In this study, the modified pyrite was used as the fillings of sequencing batch reactor (SBR) in order to improve the efficiencies of nitrogen and phosphorus removal from wastewater. The results showed that SBR with the modified pyrite could significantly improve the removal efficiencies of nitrogen and phosphorus when compared with that in SBR without fillings (control SBR). The average influent ammonia nitrogen $\left(\mathrm{NH}_{4}{ }^{+}-\mathrm{N}\right)$ and total phosphorus (TP) were $6.96 \pm 0.17 \mathrm{mg} \mathrm{L}^{-1}$ and $6.94 \pm 0.01 \mathrm{mg} \mathrm{L}^{-1}$, respectively. The average $\mathrm{NH}_{4}{ }^{+}-\mathrm{N}$ and TP removals of modified pyrite constructed SBR were $49.65 \pm 19.49 \%$ with $3.54 \pm 1.31 \mathrm{mg} \mathrm{L}^{-1}$ of average effluent $\mathrm{NH}_{4}{ }^{+}-\mathrm{N}$ and $76.20 \pm 6.55 \%$ with $1.84 \pm 0.46$ $\mathrm{mg} \mathrm{L}^{-1}$ of average effluent TP, respectively. While the average $\mathrm{NH}_{4}{ }^{+}-\mathrm{N}$ and TP removal efficiencies of control SBR were only $34.76 \pm 11.28 \%$ and $56.28 \pm 0.11 \%$. The mechanisms of the SBR with enhanced simultaneous nitrogen and phosphorus removals might be anaerobic and aerobic oxidations of modified pyrite, and phosphorus retained in the SBR of modified pyrite was mostly in the form of Fe-bound-P.
\end{abstract}

\section{Introduction}

Nitrogen $(\mathrm{N})$ and phosphorus $(\mathrm{P})$ discharge from wastewater to natural water are the major causes of eutrophication [1]. It is critical for the removals of $\mathrm{N}$ and $\mathrm{P}$ before wastewater discharge in order to reduce eutrophication [2]. Conventional biological $\mathrm{N}$ and $\mathrm{P}$ removal processes have been proven to be feasible, while the conventional biological techniques have some design and operational drawbacks, such as high costs and low removal rate and efficiency [3]. Therefore, it is necessary to develop an efficient and cost-effective process that can remove $\mathrm{N}$ and $\mathrm{P}$ from wastewater.

To date, various configurations of reactors have been developed to remove the $\mathrm{N}$ and $\mathrm{P}$ from wastewater, including sequencing batch reactors (SBRs), attached growth biofilm reactors, moving bed biofilm reactors (MBBRs) and upflow granular sludge reactors [4]. Among them, SBR is widely used for the treatment of $\mathrm{N}$ and P-rich wastewater. However, the operating strategies are crucial to maintaining the stable performance of SBR process and the removal efficiency of $\mathrm{N}$ and $\mathrm{P}$ in conventional SBR need to be further improvement [5].
Therefore, in order to enhance the $\mathrm{N}$ and $\mathrm{P}$ removal in SBR, the fillings promoting the removal of $\mathrm{N}$ and $P$ should be selected.

Pyrite is the most abundant and widespread mineral of authigenic iron minerals and widely applied for wastewater treatment [6]. Autotrophic denitrifiers also can use pyrite as the electron donor to reduce $\mathrm{NO}_{3}^{-}$to $\mathrm{N}_{2}$ and metabolites are ferrous ion $\left(\mathrm{Fe}^{2+}\right)$, ferric ion $\left(\mathrm{Fe}^{3+}\right)$ and ferric hydroxide, which are widely used to remove phosphate from wastewater [7]. Therefore, pyrite can be used as the fillings in SBR to simultaneously enhance simultaneous $\mathrm{N}$ and $\mathrm{P}$ removal from wastewater. Ge et al. (2019) reported that natural pyrite in the wetland could enhance simultaneous nitrogen and phosphorus removal [8]. Modified pyrite, which is called colloidal pyrite, is one of cryptocrystalline pyrite with nanometer and submicrometer-sized crystals, and has a higher chemical activity than natural pyrite due to its special structure [9]. According to the best of our knowledge, few SBRs with modified pyrite as the fillings have been studied.

SBRs were constructed with the modified pyrite as the fillings in this study. The aims of this study are to evaluate the feasibility and performance of using modified pyrite as the fillings in the SBR for

\footnotetext{
Email of all the authors: yunzheguilai@126.com; xupei19971003@163.com; Why18895303350@163.com; liweihua9@126.com; zhushuguang@ahjzu.edu.cn

*Corresponding Author: Wei-Hua Li; email: liweihua9@126.com; phone: 0551-63828258;

fax: 0551-63828258; Shu-Guang Zhu; email: zhushuguang@ahjzu.edu.cn;

phone: 0551-63828252; fax: 0551-63828252
} 
wastewater treatment on the simultaneous $\mathrm{N}$ and $\mathrm{P}$ removal.

\section{Material and Methods}

\subsection{Synthetic wastewater}

The simulated domestic wastewater was used in this study according to the previous research [9]: 300 $\mathrm{mg} \mathrm{L} \mathrm{L}^{-1}$ Glucose, $30 \mathrm{mg} \mathrm{L}^{-1} \mathrm{NH}_{4} \mathrm{Cl}, 10 \mathrm{mg} \mathrm{L}^{-1}$ $\mathrm{KH}_{2} \mathrm{PO}_{4}, \quad 300 \quad \mathrm{mg}^{-1} \quad \mathrm{CaCO}_{3}, \quad 0.42 \mathrm{mg} \mathrm{L}^{-1}$ $\mathrm{ZnSO}_{4} 7 \mathrm{H}_{2} \mathrm{O}, 0.26 \mathrm{mg} \mathrm{L}^{-1} \mathrm{CuSO}_{4} 5 \mathrm{H}_{2} \mathrm{O}, 3.1 \mathrm{mg} \mathrm{L}^{-1}$ $\mathrm{CoCl}_{2} 6 \mathrm{H}_{2} \mathrm{O}, 0.99 \mathrm{mg} \mathrm{L}^{-1} \mathrm{MnCl}_{2} 4 \mathrm{H}_{2} \mathrm{O}, 2.1 \mathrm{mg} \mathrm{L}^{-1}$ $\left(\mathrm{NH}_{4}\right)_{6} \mathrm{Mo}_{7} \mathrm{O}_{24} 4 \mathrm{H}_{2} \mathrm{O}, 0.83 \mathrm{mg} \mathrm{L} \mathrm{L}^{-1} \mathrm{NiSO}_{4} 6 \mathrm{H}_{2} \mathrm{O}$, $100 \mathrm{mg} \mathrm{L}^{-1} \mathrm{FeSO}_{4} 7 \mathrm{H}_{2} \mathrm{O}, 20 \mathrm{mg} \mathrm{L}^{-1} \mathrm{CuCl}_{2} 2 \mathrm{H}_{2} \mathrm{O}$, $50 \mathrm{mg} \mathrm{L}^{-1} \mathrm{MgCl}_{2} 6 \mathrm{H}_{2} \mathrm{O}, 20 \mathrm{mg} \mathrm{L}^{-1} \mathrm{H}_{3} \mathrm{BO}_{3}, 13 \mathrm{mg} \mathrm{L}^{-}$

1 EDTA. All chemicals used in the experiments were of analytical grade, which was obtained from Sinopharm Chemical Company, Shanghai, China.

\subsection{Experimental set-up}

Two SBRs were constructed with an internal diameter of $14 \mathrm{~cm}$ and a height of $50 \mathrm{~cm}$, forming $4 \mathrm{~L}$ working volume. The SBR was operated in a 8-h cycle under anoxic and aerobic condition sequentially. Each cycle was consisted of 1-h anoxic period and $5-\mathrm{h}$ aerobic period, following 40-min settling, 10-min effluent withdrawal and 1-h idle period. A total of $2 \mathrm{~L}$ synthetic wastewater was pumped into the SBR in the first 10 mins of a cycle. Then the reactor was completely mixed at about $220 \mathrm{rpm}$ by a mechanical stirrer. Air was supplied with a gas flow rotameter during the aerobic period. One of reactors was added about $6 \mathrm{~g}$ modified pyrite and the other was as the control group. The two reactors were inoculated with aerobic sludge of a domestic wastewater treatment plant of Hefei, China at an initial concentration of mixed liquor suspended solids (MLSS) of about $4.5 \mathrm{~g} \mathrm{~L}^{-1}$.

\subsection{Fillings}

Natural pyrite was obtained from Tongling, Anhui province, China. Before use, the natural pyrite was washed in $10 \% \mathrm{HCl}$ for $2 \mathrm{~h}$ to remove any potentially foreign compound from the pyrite and then was washed 3-4 times with ultra pure water. After that, the dried pyrite was placed in a muffle furnace ini- tially at room temperature and was heated to $650^{\circ} \mathrm{C}$ in flowing nitrogen $\left(\mathrm{N}_{2}\right)$. The final heating temperature was maintained for 5 mins. After cooling to room temperature, the modified pyrite was immediately sealed and preserved. X-ray diffraction (XRD) spectra showed that it was one of cryptocrystallinee pyrite.

\subsection{Analytical methods}

Samples from the two SBR were filtered through a $0.45 \mathrm{~m}$ membrane and stored at $4{ }^{\circ} \mathrm{C}$ before analysis. $\mathrm{NH}_{4}^{+}-\mathrm{N}, \mathrm{NO}_{2}^{-}-\mathrm{N}, \mathrm{NO}_{3}^{-}-\mathrm{N}$, MLSS and TP were measured according to the Water and Wastewater Monitoring Analysis Method (SEPA, 2002).

\section{Results and Discussion}

\subsection{Nitrogen removal}

The variations of $\mathrm{N}$ concentration in the two SBRs during the experiment period were shown in Fig 1 . The results showed that the $\mathrm{NH}_{4}{ }^{+}-\mathrm{N}$ concentration reduced from $6.84 \pm 0.27 \mathrm{mg} \mathrm{L}^{-1}$ in influent to $4.48 \pm 0.87 \mathrm{mg} \mathrm{L}^{-1}$ in effluent and $34.76 \pm 11.28 \%$ of $\mathrm{NH}_{4}{ }^{+}-\mathrm{N}$ removal efficiency was obtained in control SBR (Fig. 1A). However, in the SBR with the fillings of modified pyrite, the $\mathrm{NH}_{4}{ }^{+}-\mathrm{N}$ concentration reduced from $6.96 \pm 0.17 \mathrm{mg} \mathrm{L}^{-1}$ in influent to $3.54 \pm 1.31 \mathrm{mg} \mathrm{L}^{-1}$ in effluent (Fig. 1B). The $\mathrm{NH}_{4}{ }^{+}-\mathrm{N}$ removal efficiency was up to $49.65 \pm 19.49 \%$, which was higher than that in the control SBR (Table 1). Kong et al. (2015) reported that the integrated twostage soil infiltration bioreactor incorporated with pyrite-based denitrification demonstrated good removal performance of $\mathrm{NH}_{4}{ }^{+}-\mathrm{N}$ [10]. Ge et al. (2019) suggested that the natural pyrite had no negative effects in the removal of $\mathrm{NH}_{4}{ }^{+}-\mathrm{N}$, but enhanced total nitrogen in constructed wetland [8]. Meanwhile, the nitrate $\left(\mathrm{NO}_{3}{ }^{-}-\mathrm{N}\right)$ and nitrite $\left(\mathrm{NO}_{2}^{-}-\mathrm{N}\right)$ were also detected in two reactors (Fig. 1). The results concluded that the concentrations of $\mathrm{NO}_{3}{ }^{-}-\mathrm{N}$ and $\mathrm{NO}_{2}{ }^{-}-\mathrm{N}$ were varies slightly with reaction time and the concentration of $\mathrm{NO}_{3}^{-}-\mathrm{N}$ and $\mathrm{NO}_{2}^{-}-\mathrm{N}$ in two SBR were also similar. Therefore, the mechanism of the $\mathrm{N}$ removal in SBR with modified pyrite was highly related to anaerobic and aerobic oxidation of pyrite in the SBR [8]. 

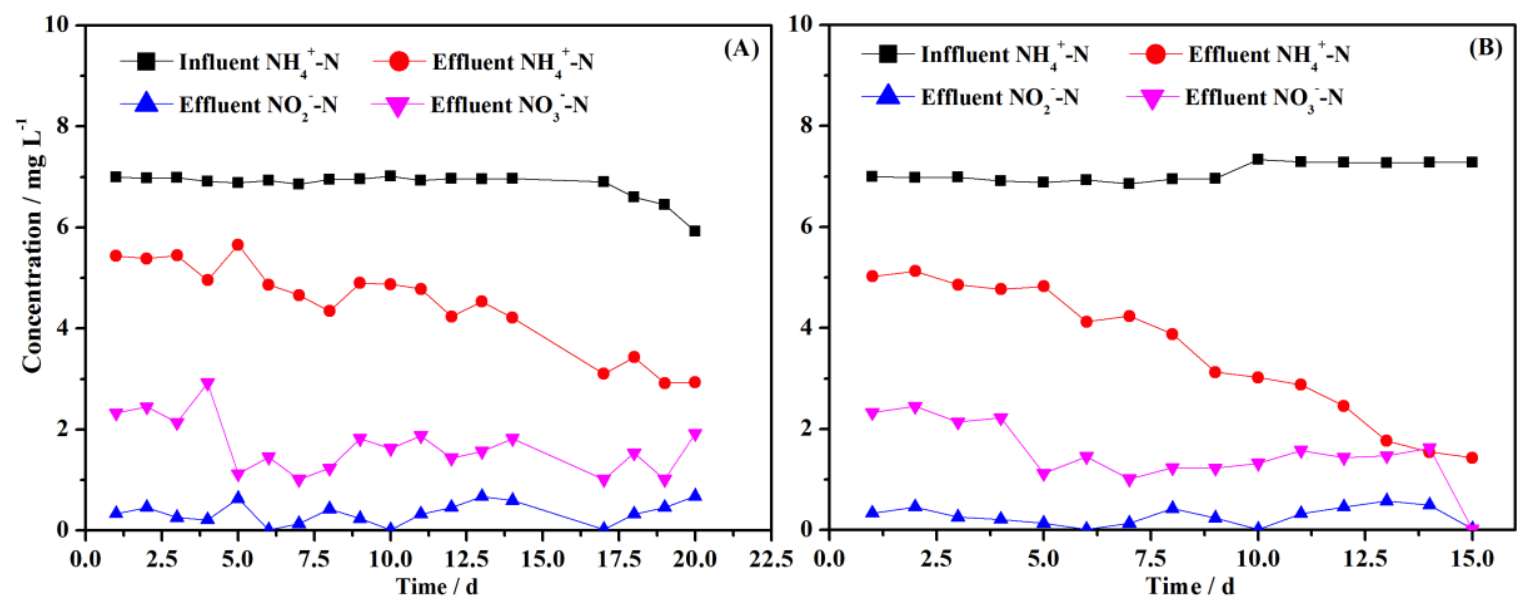

Figure 1 Nitrogen removal performance of: (A) control SBR and (B) SBR with the fillings of modified pyrite.

Table 1 Mean values of nitrogen and phosphorus removal efficiencies in the SBRs.

\begin{tabular}{ccc}
\hline Parameters & $\begin{array}{c}\text { SBR with modi- } \\
\text { fied Pyrite }\end{array}$ & Control SBR \\
\hline $\begin{array}{c}\mathrm{NH}_{4}{ }^{+}-\mathrm{N} \mathrm{re}- \\
\text { moval (\%) }\end{array}$ & $49.65 \pm 19.49 \%$ & $34.76 \pm 11.28 \%$ \\
\hline $\begin{array}{c}\text { TP removal } \\
(\%)\end{array}$ & $76.20 \pm 6.55 \%$ & $56.28 \pm 11.47 \%$ \\
\hline
\end{tabular}

\subsection{Phosphorus removal}

As shown in Fig. 2, TP concentration decreased from $6.93 \pm 0.14 \mathrm{mg} \mathrm{L}^{-1}$ in effluent of SBR with the fillings and $6.94 \pm 0.01 \mathrm{mg} \mathrm{L}^{-1}$ in effluent of control SBR to $3.03 \pm 0.81 \mathrm{mg} \mathrm{L}^{-1}$ and $1.84 \pm 0.46 \mathrm{mg} \mathrm{L}^{-1}$, respectively. The TP removal efficiency in SBR

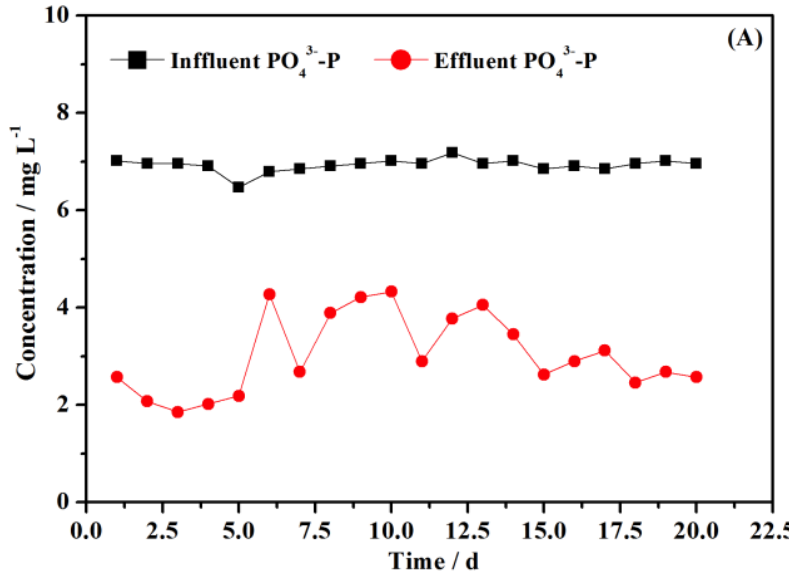

(A)

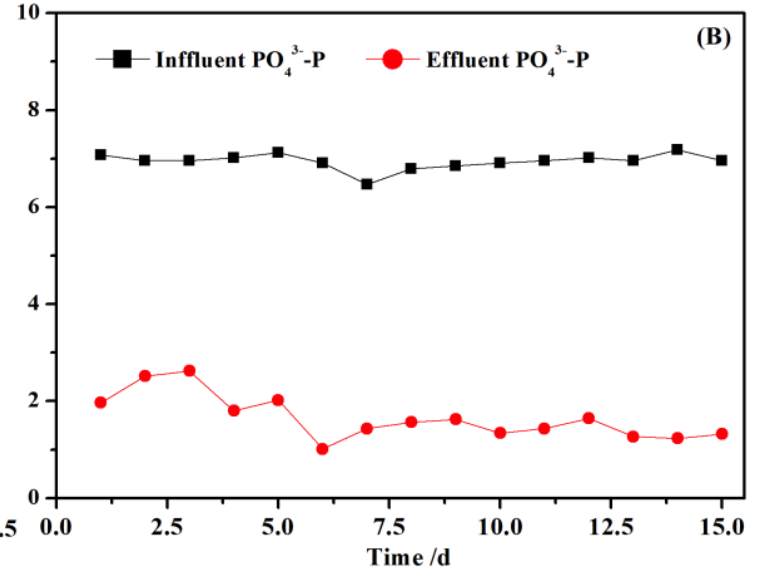

Figure 2 Phosphorus removal performance of: (A) control SBR and (B) SBR with the fillings of modified pyrite.

\section{Conclusions}

SBR was constructed with modified pyrite as the fillings, which concluded that modified pyrite had positive effects on the removal of nitrogen and phosphorus from wastewater. The average $\mathrm{NH}_{4}{ }^{+}-\mathrm{N}$ and TP removal efficiencies in SBR with modified pyrite were $49.65 \pm 19.49 \%$ and $76.20 \pm 6.55 \%$, respectively. The main mechanisms of simultaneous with the fillings was $76.20 \pm 6.55 \%$, which was higher than the removal efficiency of $56.28 \pm 11.47 \%$ in the control SBR (Table 1). The results suggested that the SBR with modified pyrite had more excellent TP removal performance for wastewater treatment, which was consistent with the results of Kong et al. (2015) and Ge et al. (2019) [8,10]. According to the previous studies, the phosphorus could be used as nutrient for bacteria growing or enzyme composing and be essential in autotrophic denitrification [11,12]. And Zhu et al. (2011) reported that phosphate-accumulating organisms (PAOs) would uptake $\mathrm{PO}_{4}{ }^{3-}-\mathrm{P}$ when the carbon source was sufficient [13]. Moreover, $\mathrm{PO}_{4}{ }^{3-}-\mathrm{P}$ could be adsorbed by $\mathrm{Fe}^{3+}$ or $\mathrm{Fe}(\mathrm{OH})_{3}$ produced by modified pyrite in SBR $[14,15]$. While the latest study suggested that phosphorus removal was mostly in form of $\mathrm{Fe}$ bound-P [8].

nitrogen and phosphorus removal may be anaerobic and aerobic oxidations of modified pyrite, and phosphorus reserved in the SBR was mainly in form of Fe-bound-P. Future studies should focus on confirming the role of modified pyrite on the removal of $\mathrm{N}$ and $\mathrm{P}$ and optimizing the key factors such as the particle size. 


\section{Acknowledgements}

This research was financially supported by the Startup Fund for Talents of Anhui Jianzhu University (Grant No. 2018QD05), the Key University Natural Science Research Project of Anhui Province (Grant No. KJ2019A0735), Anhui Key Project of Research and Development Plan (Grant No. 1704a0902006 and 201904a07020070) and Major Science and Technology Project of Anhui Province (Grant No. 17030801028).

\section{References}

1. Li, R.H., Morrison, L., Collins, G., Li, A.M., Zhan, X.M. (2016) Simultaneous nitrate and phosphate removal fromwastewater lacking organic matter through microbial oxidation of pyrrhotite coupled to nitrate reduction. Water Res., 96: 32-41.

2. Conley, D.J., Paerl, H.W., Howarth, R.W., Boesch, D.F., Seitzinger, S.P., Havens, K.E., Lancelot, C., Likens, G.E. (2009) Ecology controlling eutrophication: nitrogen and phosphorus. Science, 323 (5917): 1014-1015.

3. Shi, L.L., Ma, B., Li, X.Y., Zhang, Q., Peng, Y.Z. (2019) Advanced nitrogen removal without addition of external carbon source in an anaerobic/aerobic/anoxic sequencing batch reactor. Bioproc. Biosyst. Eng., 42: 1507-1515.

4. Choi, D., Cho, K., Jung, J. (2019) Optimization of nitrogen removal performance in a single-stage SBR based on partial nitritation and ANAMMOX. Water Res., 162: 105-114.

5. Lackner, S., Horn, H. (2013) Comparing the performance and operation stability of an SBR and MBBR for single-stage nitritation-anammox treating wastewater with high organic load. Environ. Technol., 34 (10): 1319-1328.

6. Yang, Y., Chen, T., Sumona, M., Gupta, B.S., Sun, Y., Hu, Z., Zhan, X. (2017) Utilization of iron sulfides for wastewater treatment: a critical review. Rev. Environ. Sci. Biotechnol., 16 (2): 289-308.

7. Li, R.H., Lin, Z., Tao, T., Bo, L. (2011) Phosphorus removal performance of acid mine drainage from wastewater. J. Hazard. Mater., 190 (1): 669-676.

8. Ge, Z.B., Wei, D.Y., Zhang, J., Hu, J.S., Liu, Z., Li, R.H. (2019) Natural pyrite to enhance simultaneous long-term nitrogen and phosphorus removal in constructed wetland: Three years of pilot study. Water Res., 148: 153-161.

9. Yang, Y., Chen, T.H., Li, P., Qing, C.S., Xie, Q.Q., Zhan, X.M. (2016) Immobilization of copper under an acid leach of colloidal pyrite waste rocks by a fixed-bed column. Environ. Earth Sci., 75: 205-213.

10. Kong, Z., Li, L., Feng, C.P., Chen, N., Dong, S.S., Hu, W.W. (2015) Soil infiltration bioreactor incorporated with pyrite-based (mixotrophic) denitrification for domestic wastewater treatment. Bioresource Tcchnol., 187: 14-22.
11. Bruser, T., Selmer, T., Dahl, C. (2000) 'ADP sulfurylase' from Thiobacillus denitrificansss an adenylylsulfate: phosphate adenylyltransferase and belongs to a new family of nucleotidyltransferases. J. Biol. Chem., 1691-1698.

12. Moon, H.S., Shin, D.Y., Nam, K., Kim, J.Y. (2008) A long-term performance test on an autotrophic denitrification column for application as a permeable reactive barrier. Chemosphere, 73: 723-728.

13.Zhu, R., Wu, M., Zhu, H.G., Wang, Y.J., Yang, J. (2011) Enhanced phosphorus removal by a humus soil cooperated sequencing batch reactor using acetate as carbon source. Chem. Eng. J., 166: 687-692.

14. Caravelli, A.H., Gregorio, G.D., Zaritzky, N.E. (2012) Effect of operating conditions on the chemical phosphorus removal using ferric chloride by evaluating orthophosphate precipitation and sedimentation of formed precipitates in batch and continuous systems. Chem. Eng. J., 209: 469-477.

15. Tang, X.Q., Wu, M., Dai, X.C., Chai, P.H. (2014) Phosphorus storage dynamics and adsorption characteristics for sediment from a drinking water source reservoir and its relation with sediment compositions. Ecol. Eng., 64: 276-284. 